\title{
ACUTE COPPER TOXICITY IN THE EURYHALINE COPEPOD ACARTIA TONSA: IMPLICATIONS FOR THE DEVELOPMENT OF AN ESTUARINE AND MARINE BIOTIC LIGAND MODEL
}

\author{
Grasiela Lopes Leães Pinho $†$ and Adalto Bianchini* $\ddagger$ \\ $\dagger$ Instituto de Oceanografia, łInstituto de Ciências Biológicas, \\ Universidade Federal do Rio Grande, Av. Itália km 8, 96.201-900 Rio Grande, Rio Grande do Sul, Brazil
}

(Submitted 4 November 2009; Returned for Revision 17 March 2010; Accepted 18 March 2010)

\begin{abstract}
Copepods (Acartia tonsa) were exposed (48 h) to waterborne, diet-borne (non-Cu-equilibrated and Cu-equilibrated food), and waterborne plus diet-borne $\mathrm{Cu}$ in either the absence or the presence of food (diatom Thalassiosira weissflogii). Toxicity tests were run in different salinities $(5,15$, and $30 \mathrm{ppt})$ together with measurements of physicochemical parameters and total and dissolved $\mathrm{Cu}$ concentrations in the experimental media. Results show that most of the toxic $\mathrm{Cu}$ fraction was in the dissolved phase. In general, $\mathrm{Cu}$ toxicity was higher in low (5 ppt) than in high salinity (30 ppt), regardless of the pathway of Cu exposure tested. In the absence of food, data clearly indicate that differences in waterborne $\mathrm{Cu}$ toxicity can be explained by changes in water chemistry. However, addition of food (either non-Cu-equilibrated or $\mathrm{Cu}$-equilibrated) to the experimental media protected against acute $\mathrm{Cu}$ toxicity in salinities 5 and 15 ppt, suggesting that $A$. tonsa requires extra energy to cope with the stressful condition imposed by $\mathrm{Cu}$ exposure associated with the ionoregulatory requirements in low salinities. For diet-borne exposure, a very high $\mathrm{Cu}$ concentration was necessary to precontaminate the diatoms to a level resulting in copepod mortality. Therefore, availability of food exerted a more important positive impact in protecting against acute $\mathrm{Cu}$ toxicity than its potential negative impact via contamination resulting in toxicity. Findings indicate the need for incorporation of both salinity and food in a future biotic ligand model (BLM) version for Cu in estuarine and marine waters. In this context, the euryhaline copepod A. tonsa would be a suitable model species with which to perform experiments to validate and calibrate any future saltwater BLM. Environ. Toxicol. Chem. 2010;29:1834-1840. C 2010 SETAC
\end{abstract}

Keywords-Acartia tonsa Acute toxicity Biotic ligand model Copper $\quad$ Salinity

\section{INTRODUCTION}

Copper, like other metals, is in constant movement from soils to aquatic environments. Natural runoff is the main source of $\mathrm{Cu}$ in water, as a result of mining activities. Despite the existence of natural sources, industrial, agricultural, and harbor activities are continuously contributing to the increased input of $\mathrm{Cu}$ in estuarine and marine environments [1-6]. In Southern Brazil, $\mathrm{Cu}$ is the most relevant contaminant in coastal areas close to anthropogenic sources [2-4]. A marked 17-fold increase $(2-34 \mu \mathrm{g} / \mathrm{L})$ in dissolved $\mathrm{Cu}$ concentration has been reported over an approximately 20 -y period in the Patos Lagoon estuary (Southern Brazil), the largest coastal lagoon in South America [1-4].

The presence of $\mathrm{Cu}$ at low concentrations in the aquatic media is very important because of its role in a number of physiological processes. However, when a threshold concentration is reached, normally associated with anthropogenic activities, $\mathrm{Cu}$ can be toxic to many aquatic organisms. Thus, $\mathrm{Cu}$ discharge in the environment has to be regulated [2].

In many countries, $\mathrm{Cu}$ emission is regulated based only on the total metal concentration in either effluents or in the environment. In both cases, water chemistry and the potential biological effects of metal exposure are not considered. However, it is well known that the chemistry of trace metals in water and, consequently, their toxicity are determined typically by complexation, biological uptake, and sorption on suspended solids $[7,8]$. Thus, to predict metal toxicity in aquatic systems, it

* To whom correspondence may be addressed (adaltobianchini@furg.br).

Published online 19 April 2010 in Wiley InterScience (www.interscience.wiley.com). is important to consider not only the metal concentration in the water but also the potential influence of many physicochemical parameters of the water on metal bioavailability. In 1985, the U.S. Environment Protection Agency (U.S. EPA), acknowledging the interaction between metals and different substances in water, adjusted the maximum allowed concentrations of metals in water by considering the water hardness [9]. However, this re-evaluation, though providing more environmentally relevant values than the former regulations, was still incomplete, insofar as it overlooked other key factors affecting metal toxicity. For example, water parameters such as $\mathrm{pH}[10,11]$, cation and sulfide concentrations [7], dissolved organic matter [11-13], hardness [10,12], suspended particulate matter [8], salinity [14], and ion composition [15] have been shown to influence $\mathrm{Cu}$ bioavailability and toxicity. Thus, it is clear that the environmental risk assessment of metals is not a simple task.

Protective effects of various water chemistry parameters were then incorporated into the biotic ligand model (BLM) for $\mathrm{Cu}$ [16]. This model simultaneously accounts for the speciation and complexation of dissolved metal and competitive binding of metal and other cations at the site of action. The fundamental premise of the BLM is that metal concentration in/ on the target is correlated with the acute toxicity of the metal $[17,18]$. This model has now been adopted by the U.S. and Australia/New Zealand Environmental Protection Agencies as a legal tool for managing environmental regulatory issues concerning metal release in the aquatic environment. It is also in the process of being adopted by Environment Canada and the European Union.

Another important factor to be considered is the influence of the route of exposure on metal toxicity. Because organisms can 
be exposed to contaminants both directly (dissolved metal in the water) and indirectly (trophic transfer), toxicological testing has to address the importance of the different routes of exposure. For example, food can influence metal toxicity, not only by altering water chemistry but also by altering the amount of metal accumulated. Furthermore, it has been previously demonstrated that nutrition can have an influence on the response of field populations of calanoid copepods to $\mathrm{Cu}$ exposure [19]. More recently, it has been determined that metal contamination via food, including $\mathrm{Cu}$, has toxic effects on copepods [20-22].

Therefore, it is clear that water chemistry and the presence of food in the experimental medium could alter $\mathrm{Cu}$ toxicity to aquatic animals. Unfortunately, most of the information and knowledge on $\mathrm{Cu}$ toxicity in invertebrates reported so far is available only for freshwater environments after acute exposure, a situation that normally does not involve the presence of food in water.

Based on this background, the main goal of the present study was to determine the effects of both salinity and the pathway of exposure on acute $\mathrm{Cu}$ toxicity in a copepod species in a wide range of salinities. Copepods are considered sensitive indicators of metal toxicity [21], being employed in toxicological studies both in the laboratory [19] and in the field [23]. The species selected to conduct the present investigation was the euryhaline copepod Acartia tonsa, because it is an euryhaline species tolerating a wide range of salinities [24,25]. Furthermore, it is cosmopolitan and a key species in the food web of estuaries and coastal waters [26].

\section{MATERIALS AND METHODS}

\section{Copepods culture and acclimation}

Copepods were cultivated according to the method described by Bersano [27]. The original lot of copepods (Acartia tonsa) was obtained from a permanent intensive culture at the University Aquaculture Marine Station (Rio Grande, RS, Southern Brazil). Copepods cultivated at salinity 30 ppt were transferred to our laboratory and kept in 10-L plastic buckets containing water and acclimated, for at least one week, to the desired experimental salinity $(5,15$, or $30 \mathrm{ppt})$. Water at different salinities was prepared by mixing filtered (1- $\mu \mathrm{m}$ mesh) seawater collected at the Cassino Beach (Rio Grande, RS, Southern Brazil) with distilled water. Seawater used in the present study was previously analyzed and considered free of major contaminants, such as metals and organics (pesticides and hydrocarbons), being used for many years in the aquaculture facilities of the Federal University of Rio Grande (Rio Grande, Rio Grande do Sul, Brazil). Copepods were fed daily with a mixed algal diet composed of the diatoms Thalassiosira weissflogii $\left(2 \times 10^{4}\right.$ cells $/ \mathrm{ml})$ and Isochrysis galbana $\left(1 \times 10^{4}\right.$ cells $\left./ \mathrm{ml}\right)$. Media were gently aerated and completely renewed every week. Room temperature was fixed at $20^{\circ} \mathrm{C}$.

\section{Acute toxicity tests}

Toxicity tests (48-h median effective concentration value [EC50]) were performed using adult copepods. Prior to experiments, adult male and female copepods (total length $0.80 \pm$ $0.09 \mathrm{~mm}$, dry wt $9.0 \pm 1.7 \mu \mathrm{g}$ ) were randomly collected from the culture using a $300-\mu \mathrm{m}$ mesh net. Standard static-renewal procedures, as used for daphnid tests [28], were used for copepods, together with direct measurements of dissolved oxygen, $\mathrm{pH}$, ion concentration $\left(\mathrm{Na}^{+}, \mathrm{Cl}^{-}, \mathrm{K}^{+}, \mathrm{SO}_{4}^{2-}, \mathrm{Mg}^{2+}\right.$, and $\mathrm{Ca}^{2+}$ ), alkalinity, dissolved organic carbon, and total and dissolved (0.45- $\mu \mathrm{m}$ mesh filter) $\mathrm{Cu}$ concentrations in the experimental media.

For waterborne exposure, $\mathrm{Cu}$ as $\mathrm{CuCl}_{2}$ (Merck) was added to water at the desired concentration from stock solutions $(0.2,2.0$, or $20 \mathrm{~g} \mathrm{Cu} / \mathrm{L}$ ) prepared with MilliQ ${ }^{\circledR}$ water acidified with $1 \%$ $\mathrm{HNO}_{3}$ (Suprapur ${ }^{\mathbb{R}}$; Merck). For waterborne exposure in the presence of non-Cu-equilibrated food, $\mathrm{Cu}$ was added to the water as described above for waterborne exposure. However, non-Cu-equilibrated food ( $T$. weissflogii) was added to the experimental medium at a final concentration of $2 \times 10^{4}$ cells $/ \mathrm{ml}$. This concentration was selected based on the fact that saturation in A. tonsa egg production was observed under this feeding condition, indicating a maximum long-term physiological performance of copepods at this algae concentration [29]. Food was added to the experimental media $3 \mathrm{~h}$ prior to copepod introduction. Food was prepared by growing algae ( $T$. weissflogii) for $3 \mathrm{~d}$ in $\mathrm{f} / 2$ medium. This is a common and widely used, general, enriched seawater medium designed for growing coastal marine algae, especially diatoms. The concentration of the original formulation, f medium, was reduced by half [30]. Growing media was prepared with filtered (1- $\mu \mathrm{m}$ mesh) and autoclaved saltwater at the desired experimental salinity $(5,15$, or $30 \mathrm{ppt}$ ). After growth, log-phase cells were counted and added to the experimental medium to achieve the desired final algae cells concentrations $\left(2 \times 10^{4}\right.$ cells $\left./ \mathrm{ml}\right)$

For waterborne plus diet-borne exposure, $\mathrm{Cu}$ was added to the experimental medium as described above for waterborne exposure. However, $\mathrm{Cu}$-equilibrated food was added to the experimental medium at a final concentration of $2 \times 10^{4}$ cells $/ \mathrm{ml}$. Food was added to the experimental media $3 \mathrm{~h}$ prior to copepod introduction. Copper-equilibrated food was prepared as previously described. It was shown that algae (T. weissflogii) were saturated with $\mathrm{Cu}$ after $24 \mathrm{~h}$ of exposure under similar experimental conditions [31]. Therefore, T. weissflogii was exposed for $24 \mathrm{~h}$ to $\mathrm{Cu}$ dissolved in saltwater at the desired experimental salinity. Copper concentrations used were the same as those employed for the copepod exposure to waterborne $\mathrm{Cu}$. After $24 \mathrm{~h}$ of exposure, $\mathrm{Cu}$-equilibrated algae cells were collected and added to fresh solutions of the experimental media, which were prepared as for the algal cells contamination. The final concentration of algal cells in the experimental media was $2 \times 10^{4}$ cells $/ \mathrm{ml}$.

For the dietborne exposure, $\mathrm{Cu}$-equilibrated cells were prepared as described above and centrifuged $(10,000 \mathrm{~g})$. The supernatant was discarded, and the pellet of algae cells obtained was resuspended in freshly prepared saltwater at the desired experimental salinity $(5,15$, or $30 \mathrm{ppt})$, and added $\left(2 \times 10^{4}\right.$ cells/ml final concentration) to the saltwater used for copepods exposure, without $\mathrm{Cu}$ addition. Measurements of $\mathrm{Cu}$ (total and dissolved) concentration in the experimental medium showed no significant metal leaching from the algae into the waterborne phase (data not shown).

For each salinity and different pathway of exposure, control tests were also run under the same experimental conditions as described above. However, no $\mathrm{Cu}$ or $\mathrm{Cu}$-equilibrated food was added to the experimental media.

All experimental media were prepared $3 \mathrm{~h}$ prior to copepod introduction. All experiments were performed in duplicate using 50-ml glass flasks properly sealed, containing $50 \mathrm{ml}$ experimental medium and 10 organisms in each. Flasks were maintained in an incubator and under constant rotation ( $2 \mathrm{rpm})$ to ensure food suspension and medium homogeneity. Temperature and photoperiod in the incubator were fixed at $20^{\circ} \mathrm{C}$ and 16:8 h light:dark, respectively. Every $24 \mathrm{~h}$, surviving copepods 
were counted and transferred using plastic pipettes to a new set of test solutions prepared $3 \mathrm{~h}$ before copepod introduction, as described above.

All materials used in the experiments had previously been acid washed in $1 \% \mathrm{HNO}_{3}$ (Merck) and rinsed thoroughly with distilled water before their use.

\section{Water chemistry}

At the start and after $24 \mathrm{~h}$ of exposure, nonfiltered and filtered $(0.45-\mu \mathrm{m}$ mesh) samples $(10 \mathrm{ml})$ from the different experimental media were collected for $\mathrm{Cu}$ concentration measurements and water chemistry analyses, as described below. Those employed for $\mathrm{Cu}$ concentration measurements were immediately acidified $\left(1 \% \mathrm{HNO}_{3}\right)$.

Total and dissolved $\mathrm{Cu}$ concentrations in the experimental media were measured by atomic absorption spectrophotometry (AAS 932 Avanta-Plus; GBC), as previously described [31]. A Cu standard solution (Standard Reference Material ${ }^{\circledR}$ 3114) from the National Institute of Standards and Technology (Gaithersburg, MD, USA) was used to check the accuracy of measurements. The detection limit of the measurement was $10 \mu \mathrm{g} / \mathrm{L} . \mathrm{Na}^{+}, \mathrm{K}^{+}$, and $\mathrm{Ca}^{2+}$ concentrations were measured by flame photometry (Micronal). $\mathrm{Mg}^{2+}$ and $\mathrm{Cl}^{-}$concentrations were measured by spectrophometric methods using commercial reagent kits (Doles). Absorbance readings $(490 \mathrm{~nm})$ were made using a microplate reader (Bio-Tek Elx-800). Water $\mathrm{pH}$ and dissolved oxygen were measured using a pH meter (Digimed DM 20) and an oximeter (Digimed DMO-2), respectively. Sulfate concentration in the experimental media was measured by using the spectrophometric method described by Tabatabai [32]. Water alkalinity was determined according to the method described by the American Public Health Association [33]. Dissolved organic carbon was measured in filtered water samples using a total organic carbon analyzer $\left(\mathrm{V}_{\mathrm{CPN}}\right.$ series; Shimadzu).

\section{Statistical analysis}

Water chemistry data were expressed as mean \pm standard deviation and were analyzed by one-way analysis of variance to detect possible differences between treatments. The significance level adopted was $95 \%$.

Accumulated mortality data after $48 \mathrm{~h}$ of test were used to calculate the 48-h EC50 values, and their corresponding 95\% confidence intervals were calculated by using Probit analysis. The EC50 values were calculated based on total and dissolved $\mathrm{Cu}$ concentrations as well as on the concentration and activity of the major $\mathrm{Cu}$ species. Copper speciation was performed with the physicochemical parameters and the dissolved $\mathrm{Cu}$ concentration measured in the absence of food (waterborne exposure) in
Visual MINTEQ software version 2.61 (KTH, Department of Land and Water, Resources Engineering, Stockholm, Sweden). It is important to note that modeling results presented are tentative, insofar as modeled speciation is strongly dependent on the quality of the speciation model used. In this context, Visual MINTEQ is a Windows version of MINTEQA2 version 4.0, which was released by the U.S. EPA in 1999. MINTEQA2 is a chemical equilibrium model for the calculation of metal speciation, solubility equilibriums, etc., for natural waters. It is probably the most widespread model used for these purposes today, and it is renowned for its stability. In all cases, the EC50 values were considered different when the $95 \%$ confidence intervals did not overlap.

\section{RESULTS}

Water chemistry data for the different experimental media are shown in Table 1. Because no significant differences were observed between data in the absence and the presence of food in the water, only one mean value for each parameter was calculated in each salinity tested. For all parameters analyzed, the mean values significantly were augmented with increasing salinity (Table 1).

The overall mean concentration of total $\mathrm{Cu}$ among all the toxicity tests performed represented $87.8 \pm 13.7 \%$ of the nominal concentrations of $\mathrm{Cu}$ added to the experimental media. In all experimental media, virtually all $\mathrm{Cu}$ in the water was present in the dissolved form, representing from 92.4 to $114.0 \%$ of the total measured $\mathrm{Cu}$.

In all control treatments, copepod mortality was equal to or lower than $10 \%$ over the 48 -h period of testing. In $\mathrm{Cu}$-exposed copepods, acute $\mathrm{Cu}$ toxicity was salinity dependent, the highest toxicity being observed at the lowest salinity tested (5 ppt) in almost all treatments.

In the absence of food (waterborne exposure), the 48-h EC50 values calculated based on total $\mathrm{Cu}$ concentrations were 2.7and 3.3-fold lower in salinity 5 than 15 and 30 ppt, respectively (Fig. 1A). Based on dissolved $\mathrm{Cu}$ concentrations, they were 2.1and 2.7-fold lower in salinity 5 than 15 and 30 ppt, respectively (Fig. 1B). In all salinities, the most abundant $\mathrm{Cu}$ species were $\mathrm{CuCO}_{3}$ and the free ion $\left(\mathrm{Cu}^{2+}\right)$, followed by $\mathrm{CuOH}^{+}$. At salinity $30 \mathrm{ppt}$, an important amount of $\mathrm{Cu}\left(\mathrm{CO}_{3}\right)_{2}^{2-}$ was also observed (Fig. 2). In general, the 48-h EC50 values based on the free $\mathrm{Cu}$ (and $\mathrm{Cu}$ activity), $\mathrm{CuOH}^{+}$, and $\mathrm{Cu}(\mathrm{OH})_{2}$ concentrations did not show marked changes at the different experimental salinities. However, toxicity values based on $\mathrm{CuCO}_{3}$, and $\mathrm{Cu}\left(\mathrm{CO}_{3}\right)_{2}^{2-}$ concentrations significantly increased with increasing salinities (Fig. 2).

Table 1. Water chemistry for the different experimental media employed to perform experiments with the copepod Acartia tonsa

\begin{tabular}{|c|c|c|c|}
\hline \multirow[b]{2}{*}{ Parameter } & \multicolumn{3}{|c|}{ Salinity (ppt) } \\
\hline & 5 & 15 & 30 \\
\hline $\mathrm{pH}$ & $7.25 \pm 0.05 \mathrm{~A}$ & $7.28 \pm 0.03 \mathrm{~A}$ & $7.72 \pm 0.03 \mathrm{~B}$ \\
\hline Dissolved oxygen $\left(\mathrm{mmol} \mathrm{O}_{2} / \mathrm{L}\right)$ & $0.26 \pm 0.002 \mathrm{~A}$ & $0.25 \pm 0.001 \mathrm{~A}$ & $0.19 \pm 0.002 \mathrm{~B}$ \\
\hline $\mathrm{Na}^{+}(\mathrm{mmol} / \mathrm{L})$ & $70.5 \pm 1.3 \mathrm{~A}$ & $240.0 \pm 11.2 \mathrm{~B}$ & $462.0 \pm 4.5 \mathrm{C}$ \\
\hline $\mathrm{Cl}^{-}(\mathrm{mmol} / \mathrm{L})$ & $88.4 \pm 1.0 \mathrm{~A}$ & $296.0 \pm 13.8 \mathrm{~B}$ & $512.3 \pm 15.6 \mathrm{C}$ \\
\hline $\mathrm{K}^{+}(\mathrm{mmol} / \mathrm{L})$ & $1.37 \pm 0.07 \mathrm{~A}$ & $4.04 \pm 0.15 B$ & $8.60 \pm 0.72 \mathrm{C}$ \\
\hline $\mathrm{Ca}^{2+}(\mathrm{mmol} / \mathrm{L})$ & $1.73 \pm 0.00 \mathrm{~A}$ & $4.65 \pm 0.31 \mathrm{~B}$ & $8.50 \pm 0.58 \mathrm{C}$ \\
\hline $\mathrm{Mg}^{2+}(\mathrm{mmol} / \mathrm{L})$ & $5.80 \pm 0.02 \mathrm{~A}$ & $22.4 \pm 0.70 \mathrm{~B}$ & $39.16 \pm 3.17 \mathrm{C}$ \\
\hline $\mathrm{SO}_{4}^{2-}(\mathrm{mmol} / \mathrm{L})$ & $1.11 \pm 0.04 \mathrm{~A}$ & $4.40 \pm 0.08 \mathrm{~B}$ & $7.68 \pm 0.09 \mathrm{C}$ \\
\hline Alkalinity $\left(\mathrm{mmol} \mathrm{CaCO}_{3} / \mathrm{L}\right)$ & $0.38 \pm 0.002 \mathrm{~A}$ & $1.06 \pm 0.003 \mathrm{~B}$ & $2.41 \pm 0.002 \mathrm{C}$ \\
\hline Dissolved organic carbon (mg C/L) & $0.129 \pm 0.068 \mathrm{~A}$ & $0.736 \pm 0.113 \mathrm{~B}$ & $1.172 \pm 0.098 \mathrm{C}$ \\
\hline
\end{tabular}

\footnotetext{
${ }^{\mathrm{a}}$ Different letters represent significant different mean values within salinities for each parameter.
} 

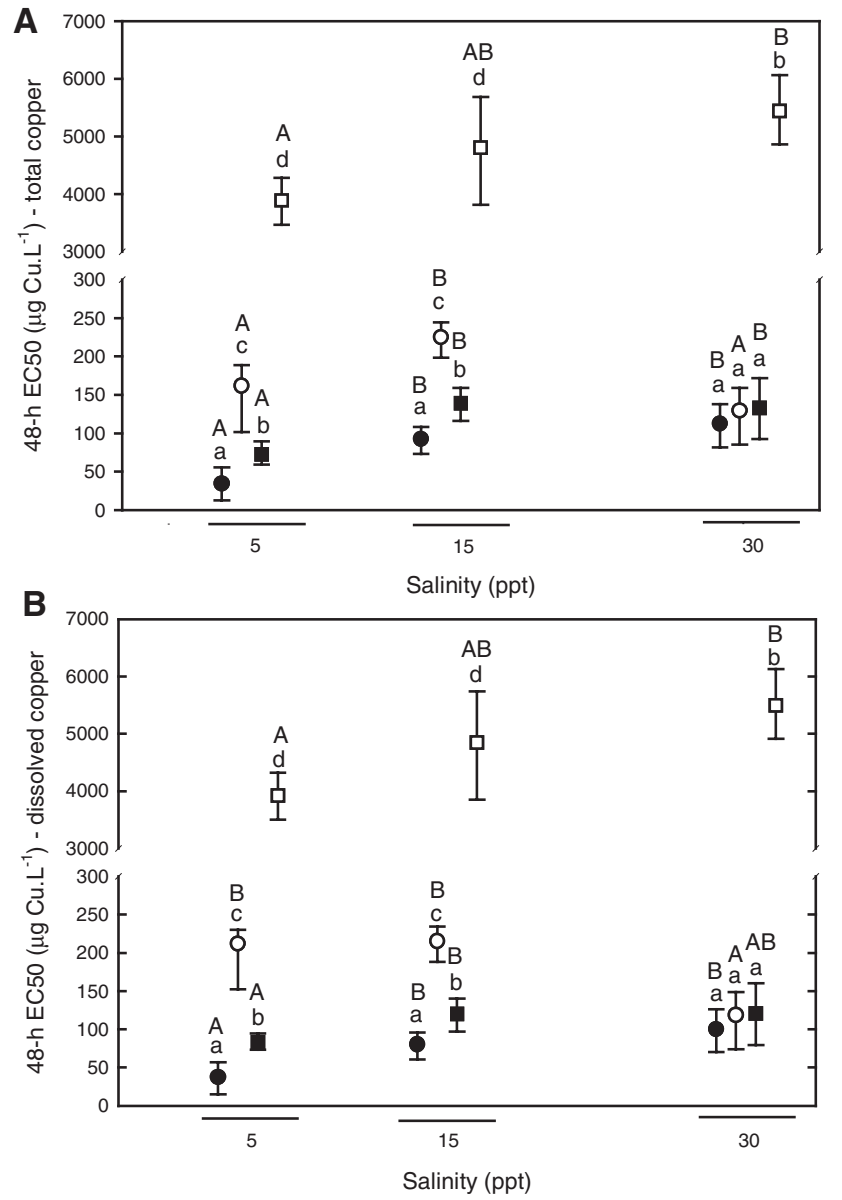

Fig. 1. Acute copper toxicity in the euryhaline copepod Acartia tonsa in a wide range of salinities. Four different pathways of $\mathrm{Cu}$ exposure were tested: waterborne $\mathrm{Cu}$ ( $\mathrm{Cu}$ added to the water without food; solid circles), waterborne plus food ( $\mathrm{Cu}$ and non-Cu-equilibrated food added to the water; open circles), waterborne plus diet-borne $(\mathrm{Cu}$ and $\mathrm{Cu}$-equilibrated food added to the water; solid squares), and diet-borne (Cu-equilibrated food added to clean water; open squares). Data are expressed as 48-h median effective concentration values (EC50) and their corresponding 95\% confidence intervals. Values were calculated based on total (A) and dissolved (B) $\mathrm{Cu}$ concentrations. Different lowercase letters indicate different 48-h EC50 values between treatments for the same salinity. Different capital letters indicate different 48$\mathrm{h}$ EC50 values between salinities for the same treatment.

In the presence of non-Cu-equilibrated food in the water (waterborne plus food), the influence of salinity on acute $\mathrm{Cu}$ toxicity was less marked, and a different pattern was observed when 48-h EC50 values were calculated using total and dissolved $\mathrm{Cu}$ concentrations. Based on total $\mathrm{Cu}$ concentrations, the 48-h EC50 value was 1.4-fold lower in salinity 5 than $15 \mathrm{ppt}$ (Fig. 1A). However, no significant difference was observed when the 48-h EC50 values were calculated based on dissolved $\mathrm{Cu}$ concentrations. Based on total $\mathrm{Cu}$ concentrations, no significant difference was observed between the 48-h EC50 values in salinities 5 and $30 \mathrm{ppt}$, but the acute $\mathrm{Cu}$ toxicity was 1.6-fold lower in salinity 15 ppt (Fig. 1A). When dissolved $\mathrm{Cu}$ concentrations were considered, acute $\mathrm{Cu}$ toxicity was 1.8 -fold lower in salinities 5 and 15 than 30 ppt (Fig. 1B).

When $\mathrm{Cu}$-equilibrated food was added to the contaminated water (waterborne plus diet-borne exposure), 48-h EC50 values calculated based on total measured $\mathrm{Cu}$ concentrations were 1.9and 1.6-fold lower in salinity 5 than 15 and $30 \mathrm{ppt}$, respectively (Fig. 1A). Based on total dissolved $\mathrm{Cu}$ concentration concentrations, acute $\mathrm{Cu}$ toxicity was 1.4 -fold lower in salinity 5 than

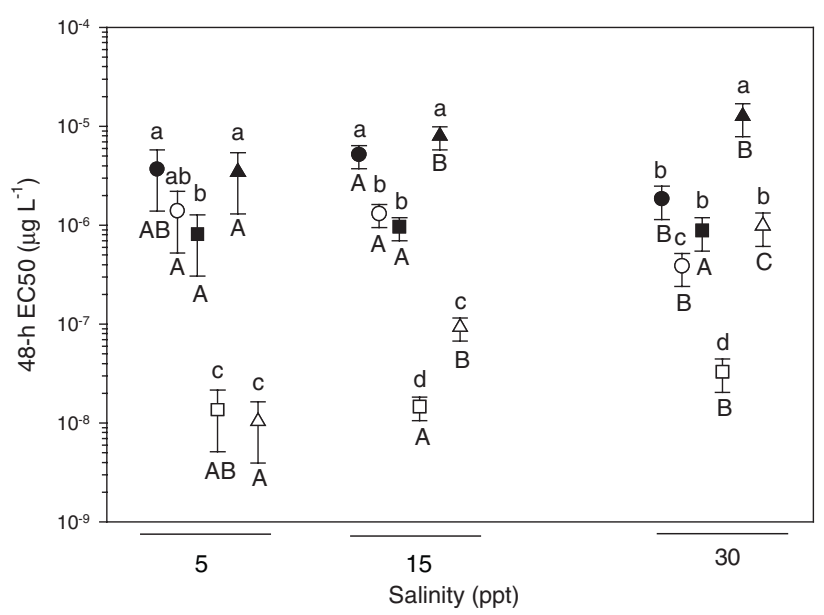

Fig. 2. Acute toxicity of different copper species in the euryhaline copepod Acartia tonsa in the absence of food in a wide range of salinities. Free $\mathrm{Cu}$ (solid circles), free $\mathrm{Cu}$ activity (open circles), $\mathrm{CuOH}^{+}$(solid squares), $\mathrm{Cu}(\mathrm{OH})_{2}$ (open squares), $\mathrm{CuCO}_{3}$ (solid triangles), and $\mathrm{Cu}\left(\mathrm{CO}_{3}\right)_{2}^{2-}$ (open triangles). Copper speciation was performed based on the 48-h median effective concentration values (EC50) and their corresponding 95\% confidence intervals calculated based on dissolved $\mathrm{Cu}$ concentrations in the absence of food (waterborne $\mathrm{Cu}$ exposure). Data are expressed as 48-h EC50 values and their corresponding 95\% confidence intervals. Different lowercase letters indicate different 48-h EC50 values between treatments for the same salinity. Different capital letters indicate different 48-h EC50 values between salinities for the same treatment

15 ppt. However, no significant difference was observed between the 48-h EC50 values at salinities 5 and $30 \mathrm{ppt}$ (Fig. 1B).

In the experiments in which copepods were exposed to $\mathrm{Cu}$ only via food (diet-borne exposure), the 48-h EC50 value calculated based on total $\mathrm{Cu}$ concentrations was 1.4-fold lower in salinity 5 than 30 ppt. No significant difference was observed between the 48-h EC50 values in salinities 5 and $15 \mathrm{ppt}$ (Fig. 1A). Based on dissolved $\mathrm{Cu}$ concentrations, they were 1.2 - and 1.4-fold lower in salinity 5 than 15 and 30 ppt, respectively (Fig. 1B).

The 48-h EC50 values were significantly higher in the presence of food (non-Cu-equilibrated or $\mathrm{Cu}$-equilibrated) than in the absence of food in the water in salinities 5 and $15 \mathrm{ppt}$. However, food did not significantly alter the acute waterborne $\mathrm{Cu}$ toxicity in salinity $30 \mathrm{ppt}$ (Fig. 1A,B).

\section{DISCUSSION}

In the present study, the influence of salinity and route of exposure on acute $\mathrm{Cu}$ toxicity was analyzed in the euryhaline copepod $A$. tonsa acclimated to different salinities $(5,15$, and $30 \mathrm{ppt}$ ) together with measurements of water chemistry and $\mathrm{Cu}$ concentrations in the experimental media. Toxicity data (48-h EC50 values) clearly show a protective effect of salinity against the acute $\mathrm{Cu}$ toxicity both in the absence and in the presence of food. This protective effect is very marked in the range of salinities from 5 to $15 \mathrm{ppt}$, being less important in the range of salinities from 15 to $30 \mathrm{ppt}$. A protective effect of salinity against the acute $\mathrm{Cu}$ toxicity was previously reported in the literature for several euryhaline crustacean species, including A. tonsa. However, those studies were always performed in the absence of food [31,34]. Considering a possible future extension of the BLM for $\mathrm{Cu}$ to estuarine and marine conditions, our results combined with those reported in the literature for other euryhaline crustacean species (isopods and crabs) under similar 
experimental conditions [34] clearly indicate that the copepod A. tonsa would be much more suitable to validate and calibrate an "estuarine and marine BLM."' This statement is based on the fact that copepods were much more sensitive to acute waterborne $\mathrm{Cu}$ exposure than isopods and crabs. Despite the fact that they are less sensitive to $\mathrm{Cu}$ than other organisms in seawater, such as developing embryos of blue mussels [35], they have great advantages for development of a saltwater BLM because they are truly euryhaline.

The protective effect of salinity against the acute $\mathrm{Cu}$ toxicity can be explained by considering the water chemistry of the experimental media employed for waterborne $\mathrm{Cu}$ exposure. For example, $\mathrm{Cu}$ complexation with dissolved organic matter and inorganic ions (anions) is augmented as salinity increases because of an increasing higher dissolved organic carbon and ion concentration. In this situation, less unbound $\mathrm{Cu}$ is available, decreasing its accumulation and consequent toxicity [36]. Furthermore, the cationic competition from $\mathrm{Na}^{+}, \mathrm{Ca}^{2+}, \mathrm{Mg}^{2+}, \mathrm{K}^{+}$, and $\mathrm{Sr}^{2+}$ for $\mathrm{Cu}^{2+}$ binding sites is stronger in saltwater than in freshwater, thus reducing the toxic effect of $\mathrm{Cu}$ on the biotic ligand. In summary, the salinity-dependent pattern of the acute waterborne $\mathrm{Cu}$ toxicity observed in the present study and reported in the literature for other crustacean species can be attributable to changes in water chemistry according to the environmental salinity. This idea is strongly supported by the fact that the 48-h EC50 values calculated based on the most toxic $\mathrm{Cu}$ species (the free ion) and its activity did not show marked changes over a wide range of salinities (5-30 ppt).

In addition to the salinity effect on $\mathrm{Cu}$ speciation and availability salinity can also affect the physiology of invertebrates through the demands of ionic regulation. Some aquatic invertebrates (e.g., estuarine invertebrates) respond mechanistically to salinity changes (i.e., osmoregulation) in such a way that their physiological responses interact with changes in free metal ion availabilities to control trace metal uptake rates [36]. Depending on the osmoregulatory physiology of the species, water and ions (including metals) are exchanged between the organism and the external medium at various rates in relation to the environmental salinity. An example of the possible control of trace metal uptake during osmoregulation has been demonstrated in the hyperbenthic mysid Neomysis integer. In this species, Cd toxicity was reduced at the salinity corresponding to the isosmotic point [37]. The authors concluded that reduced ionic exchange associated with osmoregulation led to a decreased uptake of metal from solution, suggesting that metal uptake may be mediated by normal cation transport mechanisms.

For the copepod A. tonsa, there is some evidence that metal uptake may indeed be mediated by osmoregulatory mechanisms. This hypothesis is based on the facts that the isosmotic point of this copepod is about salinity 36 ppt $(3.2 \%$ of $\mathrm{NaCl})$ [20] and that $\mathrm{Cu}$ uptake is reduced at salinity $36 \mathrm{ppt}$ in this species [36]. In accordance with these findings, the lowest acute waterborne $\mathrm{Cu}$ toxicity was observed in salinity $30 \mathrm{ppt}$ in the present study, the highest salinity tested and the nearest to the isosmotic point of the species.

In addition to the salinity protection against acute $\mathrm{Cu}$ toxicity discussed above, data reported in the present study indicate that the presence of food markedly decreased the acute $\mathrm{Cu}$ toxicity in low salinities ( 5 and $15 \mathrm{ppt}$ ). This protective effect at lower salinities was observed in the two treatments in which algae cells were added to the water as non-Cu-equilibrated food and $\mathrm{Cu}$-equilibrated food. However, the protective effect was more effective when non-Cu-equilibrated food was added to the water. These findings suggest that the protection against acute waterborne $\mathrm{Cu}$ toxicity by food could be associated with water chemistry changes, with algae cells acting as a biotic ligand taking $\mathrm{Cu}$ from the medium, thus reducing the amount of metal available for copepods. However, no significant changes in water chemistry were observed among the various routes of $\mathrm{Cu}$ exposure employed in the present study for each salinity. Furthermore, a study reporting the effects of chronic dietary $\mathrm{Cu}$ exposure on growth and reproduction of the freshwater invertebrate Daphnia magna [38] demonstrated that both pathways (waterborne and waterborne plus diet-borne) of metal exposure were toxic to reproduction in the highest $\mathrm{Cu}$ concentration tested. However, with $\mathrm{Cu}$ concentrations below the highest one tested in that study, diet-borne and waterborne plus dietborne exposures were actually beneficial to reproduction in D. magna, whereas only waterborne $\mathrm{Cu}$ did not present this favorable effect. Except in the highest $\mathrm{Cu}$ concentration tested, dietary $\mathrm{Cu}$ clearly resulted in an increased $\mathrm{Cu}$ uptake, but without toxic effects. Therefore, other aspects must be involved in the protective role of food against the acute waterborne $\mathrm{Cu}$ toxicity. Some physiological aspects are considered and discussed below.

An important physiological aspect directly associated with the stress susceptibility in aquatic invertebrates is the nourishment condition of the affected animals. For instance, it has been shown that copepods are more tolerant to salinity variations, especially in low salinities, when fed than when starved [26]. We have reported that A. tonsa show higher rates of food (algae cells) consumption in low salinities than in seawater [31]. Also, the metabolism of A. tonsa has been reported to be higher in low salinities than in seawater [39]. Finally, it has been shown that A. tonsa is a hyperosmoregulator in low salinities but an osmoconformer in seawater [24,25]. Taken together, these findings clearly indicate that A. tonsa requires extra ions and energy in low salinities to counteract actively the ion losses from the animal to the diluted media at energy expenses. In this case, the presence of food in the experimental medium would be providing the extra ions and energy required by copepods to cope with the stressful condition imposed by the osmotic gradient and the acute waterborne $\mathrm{Cu}$ exposure in low salinities. In fact, we have demonstrated that the continuous presence of food in the water effectively blocks the ionic disturbance induced by waterborne $\mathrm{Cu}$ in $A$. tonsa exposed in high salinities (15 and $30 \mathrm{ppt}$ ) and reduces the $\mathrm{Cu}$ effect in low salinity (5 ppt) [31]. Furthermore, we have demonstrated that the continuous presence of food in the water also completely blocks the chronic inhibitory effect of $\mathrm{Cu}$ on $A$. tonsa reproduction (Pinho et al., unpublished data). The fact that food markedly protected against the waterborne $\mathrm{Cu}$ toxicity in low salinity (5 ppt) and did not alter this toxicity in seawater (salinity $30 \mathrm{ppt}$ ) in the present study is also in complete agreement with the findings discussed above.

For marine herbivores, including the copepod A. tonsa, it has been demonstrated that $\mathrm{Cu}$ can be accumulated from both waterborne and diet-borne exposure. Thus, it would be expected that simultaneous $\mathrm{Cu}$ accumulation from both dissolved phase and food would increase the whole-body $\mathrm{Cu}$ accumulation and consequently the acute $\mathrm{Cu}$ toxicity in the copepod $\mathrm{A}$. tonsa. However, an opposite response was observed, insofar as acute $\mathrm{Cu}$ toxicity was lower in the presence than in the absence of $\mathrm{Cu}$ equilibrated food at low salinities (5 and $15 \mathrm{ppt})$. Furthermore, no significant changes were observed at the highest salinity (30 ppt). This lack of increased toxicity in the presence of food could be related to the differential metal distribution in internal 
organs after exposure via different pathways, resulting in different degrees of toxicity [40]. Thus, if more $\mathrm{Cu}$ is accumulated after the waterborne plus diet-borne $\mathrm{Cu}$ exposure, this metal is either binding on molecules associated with metal detoxification (e.g., metallothioneins, glutathione, etc.) or on sites not directly related to acute $\mathrm{Cu}$ toxicity. Finally, the extremely high $\mathrm{Cu}$ concentrations needed to contaminate food with a $\mathrm{Cu}$ level high enough to induce toxicity in A. tonsa after diet-borne exposure clearly indicate that food is acting much more as a protective factor against the acute $\mathrm{Cu}$ toxicity than as a vector of $\mathrm{Cu}$ contamination and toxicity in A. tonsa. In this context, the protective influence of food could be incorporated in a future saltwater BLM version considering the amount of energy and/or carbon in the natural food source needed for the tested species to achieve a maximum physiological performance (osmoregulation, growth, and reproduction) at different ambient salinities. For example, the concentration of $20 \times 10^{3}$ algae cells $\cdot \mathrm{ml}^{-1}$ ( $\sim 500 \mathrm{mg} \mathrm{C} \cdot \mathrm{L}^{-1}$ ) corresponded to the amount of energy/carbon needed for copepods $A$. tonsa to cope with osmotic stress, to block acute and chronic disturbances induced by waterborne $\mathrm{Cu}$, and to achieve maximum egg production and hatching [29,31], as discussed above.

In conclusion, we report in this paper, for the first time, data on acute $\mathrm{Cu}$ toxicity resulting from different methods of metal exposure in a euryhaline invertebrate in a wide range of salinities. Data obtained strongly indicate that water chemistry (salinity) has an important protective role against the acute waterborne $\mathrm{Cu}$ toxicity in the euryhaline copepod $A$. tonsa. Moreover, we show that food is a protective factor against the acute waterborne $\mathrm{Cu}$ toxicity rather than an important vector of $\mathrm{Cu}$ contamination and toxicity in A. tonsa.

The findings described in the present paper will be valuable for a better understanding of the relationship among salinity, food, and $\mathrm{Cu}$ speciation, bioaccumulation, and toxicity in euryhaline invertebrates. Thus, they will be useful for the extension of a future version of the $\mathrm{Cu}$ BLM for estuarine and marine conditions, and the consequent generation of BLM-derived water quality criteria for $\mathrm{Cu}$ to be applied in estuarine and marine waters. Our data strongly suggest that the euryhaline copepod A. tonsa would be a suitable species with which to validate and calibrate this future BLM version.

Acknowledgement-This study was financially supported by the International Copper Association (USA) and the Conselho Nacional de Desenvolvimento Científico e Tecnológico (CNPq, Brazil) under the scope of the Instituto Nacional de Ciência e Tecnologia de Toxicologia Aquática (CNPq, Brazil). A. Bianchini is a research fellow from the Brazilian CNPq (Proc. 300906/2006-4)

\section{REFERENCES}

1. Seeliger U, Knak RB. 1982. Estuarine metal monitoring in southern Brazil. Mar Pollut Bull 13:253-254.

2. Baumgarten MGZ, Niencheski LFH. 1998. Avaliação da Qualidade Hidroquímica da Área Portuária da Cidade do Rio Grande (RS) Documentos Técnicos-Oceanografia, Vol 9. Editora da FURG, Rio Grande, RS, Brazil

3. Niencheski LF, Baumgarten MGZ. 2000. Distribution of particulate trace metal in the southern part of the Patos Lagoon estuary. Aquat Ecosyst Health Manag 3:515-520.

4. Niencheski LFH, Baraj B, Windom HL, França RG. 2006. Natural background assessment and its anthropogenic contamination of $\mathrm{Cd}, \mathrm{Pb}$, $\mathrm{Cu}, \mathrm{Cr}, \mathrm{Zn}, \mathrm{Al}$ and $\mathrm{Fe}$ in the sediments of the Southern area of Patos Lagoon. J Coast Res 39SI:1040-1043.

5. van Geen A, Luoma SN. 1999. The impact of human activities on sediments of San Francisco Bay, California: An overview. Mar Chem 64:1-6.

6. Morillo J, Usero J, Gracia I. 2005. Biomonitoring of trace metals in a mine-polluted estuarine system (Spain). Chemosphere 58:1421-143.
7. Bianchini A, Bowles KC. 2002. Metal sulfides in oxygenated aquatic systems: Implications for the biotic ligand model. Comp Biochem Physiol C 133:51-64.

8. Ma H, Kim SD, Allen HE, Cha DK. 2002. Effect of copper binding by suspended particulate matter on toxicity. Environ Toxicol Chem 21:710 714 .

9. U.S. Environmental Protection Agency. 1985. Ambient water quality criteria for copper - 1984. EPA/440/5- 84-031. Office of Water Regulations and Standards, Washington, DC.

10. Pagenkopf GK. 1983. Gill surface interaction model for trace-metal toxicity to fishes: Role of complexation, $\mathrm{pH}$, and water hardness. Environ Sci Technol 17:342-347.

11. Welsh PG, Skidmore JF, Spry DJ, Dixon DG, Hodson PV, Hutchinson NJ, Hickie BE. 1993. Effects of $\mathrm{pH}$ and dissolved organic carbon on the toxicity of copper to larval fathead minnow (Pimephales promelas) in natural waters of low alkalinity. Can J Fish Aquat Sci 50:1356-1362.

12. Erickson RJ, Benoit DA, Mattson VR, Nelson HP Jr, Leonard EN. 1996 The effects of water chemistry on the toxicity of copper to fathead minnows. Environ Toxicol Chem 15:181-193.

13. Brown VM, Shaw TL, Shurben DG. 1974. Aspects of water quality and the toxicity of copper to rainbow trout. Water Res 8:797-803.

14. Lores EM, Pennock JR. 1998. The effect of salinity on binding of $\mathrm{Cd}, \mathrm{Cr}, \mathrm{Cu}$ and $\mathrm{Zn}$ to dissolved organic matter. Chemosphere 37:861874.

15. Gensemer RW, Naddy RB, Stubblefield WA, Hockett R, Santore RC, Paquin P. 2002. Evaluating the role of the ion composition on the toxicity of copper to Ceriodaphnia dubia in very hard waters. Comp Biochem Physiol C 133:87-97.

16. Santore RC, Di Toro DM, Paquin PR, Allen HE, Meyer JS. 2001. Biotic ligand model of the acute toxicity of metals. 2. Application to acute copper toxicity in freshwater fish and Daphnia. Environ Toxicol Chem 20:2397-2402.

17. MacRae RK, Smith DE, Swoboda-Colberg N, Meyer JS, Bergman HL. 1999. Copper binding affinity of rainbow trout (Oncorhynchus mykiss) and brook trout (Salvelinus fontinalis) gills. Environ Toxicol Chem 18:1180-1189.

18. DiToro DM, Allen HE, Bergman HL, Meyer JS, Paquin P, Santore RS 2001. Biotic ligand model of the acute toxicity of metals. 1. Technical basis. Environ Toxicol Chem 20:2383-2396.

19. Sosnowski SL, Germond DJ, Gentile JH. 1979. The effect of nutrition on the response of field populations of the calanoid Acartia tonsa to copper. Water Res 13:449-452.

20. Hook SE, Fisher NS. 2001. Reproductive toxicity of metals in calanoid copepods. Mar Biol 138:1131-1140.

21. Hook SE, Fisher NS. 2002. Relating the reproductive toxicity of five ingested metals in calanoid copepods with sulfur affinity. Mar Environ Res 53:161-174.

22. Bielmyer GK, Grossel M, Brix KV. 2006. Toxicity of silver, zinc, copper, and nickel to the copepod Acartia tonsa exposed via a phytoplankton diet. Environ Sci Technol 40:2063-2068.

23. Bianchi F, Acri F, Bernardi A, Berton A, Boldrin A, Cammati E, Cassin D, Comaschi A. 2003. Can plankton communities be considered as bioindicators of water quality in the Lagoon of Venice? Mar Pollut Bull 46:964-971.

24. Lance J. 1965. Respiration and osmotic behaviour of the copepod Acartia tonsa in diluted sea water. Comp Biochem Physiol 14:155165.

25. Bayly IAE. 1969. The body fluids of some centropagid copepods: Total concentration and amounts of sodium and magnesium. Comp Biochem Physiol 28:1403-1409.

26. Mauchline J. 1998. Advances in Marine Biology: The Biology of Calanoid Copepods. Academic, New York, NY, USA

27. Bersano JGF. 2003. Intensive cultivation of the calanoid copepod Acatia tonsa. A potential source of live food for aquaculture. Proceedings, Word Aquaculture 2003. Salvador, BA, Brazil May 19-23, p 95.

28. Bianchini A, Bowles K, Brauner CJ, Gorsuch JW, Kramer JR, Wood CM. 2002. Evaluation of the effect of reactive sulfide on the acute toxicity of silver (I) to Daphnia magna. Part II: Toxicity results. Environ Toxicol Chem 21:1294-1300.

29. Teixeira PF, Kaminski SM, Ávila TR, Cardozo AP, Bersano JGF, Bianchini A. 2010. Diet influence on egg production in the copepod Acartia tonsa (Dana, 1896). Ann Acad Bras Ciênc (in press).

30. Guillard RRL. 1975. Culture of phytoplankton for feeding marine invertebrate animals. In Smith WL, Chanley MH, eds Culture of Marine Invertebrate Animals. Plenum, New York, NY, USA pp 26-60.

31. Pinho GLL, Pedroso MS, Rodrigues SC, Souza SS, Bianchini A. 2007. Physiological effects of copper in the euryhaline copepod Acartia tonsa: 
Waterborne versus waterborne plus dietborne exposure. Aquat Toxicol 84:62-70.

32. Tabatabai MA. 1974. A rapid method for determination of sulfate in water samples. Environ Lett 7:237-234.

33. American Public Health Association. 1999. Standard Methods for the Examination of Water and Wastewaters, 20th ed. American Public Health Association, American Water Works Association, Water Environment Federation, Washington DC.

34. Bianchini A, Pedroso MS, Said JS, Spengler A, Martins SE. 2003. Biotic ligand model in fresh and sea water in Brazil. In Lagos GE, Warner AEM, Sánchez M, eds, Copper 2003-Health, Environment and Sustainable Development. Canadian Institute of Mining, Metallurgy, and Petroleum, Montréal, PQ, pp 543-552.

35. Nadella SR, Fitzpatrick JL, Franklin N, Bucking C, Smith S, Wood CM 2009. Toxicity of dissolved $\mathrm{Cu}, \mathrm{Zn}, \mathrm{Ni}$ and $\mathrm{Cd}$ to developing embryos of the blue mussel (Mytilus trossolus). Comp Biochem Physiol C 149:340 348.

36. Rainbow PS. 1997. Ecophysiology of trace metal uptake in crustaceans Estuar Coast Shelf Sci 44:169-175.

37. Wildgust MA, Jones MB. 1998. Salinity change and the toxicity of the free cadmium ion $\left[\mathrm{Cd}^{2+}{ }_{(\mathrm{aq})}\right]$ to Neomysis integer (Crustacea: Mysidacea). Aquat Toxicol 41:187-192.

38. De Schamphelaere KAC, Janssen CR. 2004. Effects of chronic dietary copper exposure on growth and reproduction of Daphnia magna. Environ Toxicol Chem 23:2038-2047.

39. Gaudy R, Cervetto G, Pagano M. 2000. Comparison of the metabolism of Acartia clausi and A. tonsa: Influence of temperature and salinity. $J$ Exp Mar Biol Ecol 247:51-65.

40. Reinfelder JR, Fisher NS. 1991. The assimilation of elements ingested by marine copepods. Science 251:794-796. 